\title{
Using fish stomachs as samplers of the benthos: integrating long-term and broad scales
}

\author{
Jason S. Link* \\ National Marine Fisheries Service, Northeast Fisheries Science Center, Woods Hole, Massachusetts 02543, USA
}

\begin{abstract}
Sampling benthic organisms in a synoptic manner is difficult, particularly at the scale of large marine ecosystems. Several known omnivorous and benthivorous fishes were evaluated as possible samplers of the benthic community on the scale of the US northeast continental shelf ecosystem, collected from the early 1970 s to 2001. Frequency of occurrence of organisms in the diet across time was examined as an index of relative abundance. Other prey and sampling caveats were accounted for by considering only those predators that met criteria such as adequate sample size, appropriate diet compositions, asymptotic stomach-prey curves, and relative constancy of all major prey groups comprising the diet. The geographic distribution of a suite of benthic organisms found in the stomachs of predators was also examined. The benthic organisms focused on were ophiuroids, echinoids, holothuroideans, asteroids, octopods, stomatopods, cumaceans, pagurids, aphroditids, anthozoans, hydrozoans and caprellids. Of these 12 prey groups, only 3 showed a decline over time based on evidence from multiple predator stomachs. Most benthic organisms exhibited non-negative trends in an index of relative abundance, and 2 showed an increase over the time-series. Additionally, many of the organisms were widely distributed, with some concentrated more on Georges Bank and others more in the Gulf of Maine. Only 1 of 9 organisms showed a shift in distribution compared to studies from 50 yr earlier. I conclude that at broad spatial and temporal scales, the routine and systematic sampling of fish stomachs can be a useful indirect method for inferring information about benthic communities on continental shelves.
\end{abstract}

KEY WORDS: Benthic communities $\cdot$ Benthic ecology $\cdot$ Fish feeding $\cdot$ Disturbance $\cdot$ Spatial distribution $\cdot$ Abundance index $\cdot$ Georges Bank $\cdot$ Gulf of Maine $\cdot$ Continental shelves

\section{INTRODUCTION}

There has been much recent interest in the effects of fishing on marine benthic habitats and communities, with particular emphasis on how these effects can influence biodiversity and populations of economically valuable species (e.g. Jennings \& Kaiser 1998, Watling \& Norse 1998, Benaka 1999, Hall 1999, Eleftheriou 2000, Kaiser \& de Groot 2000). Fishing effects and related acute disturbances usually overwhelm ecological processes, and can cause a notable decline in both benthic macrofauna and habitat complexity (e.g. Auster et al. 1996, Jennings \& Polunin 1996, Collie et al. 1997, 2000, Thrush et al. 1998, Auster \& Langton 1999, Jennings et al. 2002). More specifically, reduc- tions in biomass, abundance and species diversity of benthic organisms in fished areas have been documented for several habitat types in various ecosystems.

Certainly the effects of fishing at localized regions and of acute disturbance events are clear (e.g. Thrush et al. 1995, Jennings \& Polunin 1996, Kaiser \& Spencer 1996, Collie et al. 1997, 2000, Engel \& Kvitek 1998, Tuck et al. 1998, Auster \& Langton 1999, Ball et al. 2000, Hall-Spencer \& Moore 2000). However, the effects are less clear at broader scales and for chronic disturbances of the ocean bottom (Kaiser 1998, 2003). Time-series of biomass and species composition of the benthos are rare, if available at all, for large marine ecosystems. Because of this dearth of information, changes in benthic production are difficult to relate to 
long- or short-term changes in fish production or to changes in biodiversity (see Frid et al. 1996). Additionally, there are few studies on the spatial distribution of benthic communities on the large scales at which fisheries operate (i.e. significant portions of continental shelves). The few studies that have attempted to synoptically sample the benthos at these broad scales literally took multiple decades to sample, process, identify, audit and analyze (e.g. Kiyko \& Pogrebov 1997, Theroux \& Wigley 1998, Frid et al. 2000). Thus, it is difficult, time-consuming, and cost-prohibitive to survey benthos, let alone determine the broad-scale and long-term dynamics of benthic communities or the extent of effects on benthic communities from fishing and similar disturbances.

The goal of the study was to evaluate an approach for addressing these critical issues that is not overly costly or complicated, i.e. to use fish stomachs as samplers of the benthos to ascertain any broad-scale, longterm changes in the benthic community of the northeast US shelf ecosystem. There are precedents for this approach in other ecosystems. For instance, cod have been used to sample shrimp abundance, distribution and length frequencies (Lilly \& Parsons 1991, Fahrig et al. 1993), dab have been used to examine changes in the community composition of the North Sea benthos (Frid \& Hall 1999), and Atlantic sturgeon have been used as a proxy for isopod population dynamics (Rachlin \& Warkentine 1997). In particular, I explored the use of fish stomachs as benthic samplers to establish and evaluate a time-series of relative abundance for major benthic macrofauna. Additionally, the fish stomachs were used to document the spatial distribution of major benthic species, and these were compared to distributions from benthic surveys conducted in the northeast shelf ecosystem during the 1950s and 1960s.

\section{MATERIALS AND METHODS}

Full details of the food habits sampling and data for the northeast US shelf ecosystem are given in Link \& Almeida (2000) and are only summarized here. From 1973 to 1981, individual stomach samples of numerous species were preserved at sea in $10 \%$ buffered formalin for later prey identification. Prey weight $(0.01 \mathrm{~g})$, number, percent composition, total stomach weight $(0.01 \mathrm{~g})$, and lengths $(\mathrm{mm})$ of fish prey were determined in the laboratory. Prey identification was to the lowest taxon feasible. Since 1981, most fish stomachs have been examined and prey identified at sea. In addition, a conversion from mass $(\mathrm{g})$ to volumetric measurement of prey $\left(0.1 \mathrm{~cm}^{3}\right)$ was initiated. Data on prey composition (\%), numbers, and lengths were also collected shipboard. To account for potential differences in the resolution of prey taxonomy between in-laboratory and atsea sampling, most prey were grouped into broad prey categories (i.e. class, order, or family), with only a few prey analyzed at the species level. A conversion factor of 1.1 was used to convert prey volumes to weights based upon regression analyses (Link \& Almeida 2000).

The use of fish stomachs was limited to those predators that (1) are known benthivores or omnivores; (2) exhibited relative constancy in the major prey observed in the stomachs across the food habits timeseries (i.e. did not switch from benthivory to piscivory, or from primarily polychaete or amphipod feeding to primarily echinoderm or mollusc feeding, etc., although the particular benthic prey composition in the diet was dynamic); (3) had adequate sample sizes (>30 per 3 yr block; Table 1); (4) had a diet composition appropriate for each prey item of interest; and (5) had asymptotic stomach-prey curves (Garrison \& Link 2000, Link \& Almeida 2000). All predators used exhibit

Table 1. Number of stomachs sampled for each benthic feeding fish used as a benthic sampler for each 3 yr block. Each year represents the mid-point of a 3 yr block in the time-series (e.g. 1974 represents 1973-1975, etc.). Italicized values represent 3 yr blocks with insufficient sample sizes $(<30)$ and were not used in the time-series indices

\begin{tabular}{|c|c|c|c|c|c|c|c|c|c|c|c|}
\hline Common name & Species name & 1974 & 1977 & 1980 & 1983 & 1986 & 1989 & 1992 & 1995 & 1998 & 2001 \\
\hline Smooth dogfish & Mustelus canis & & 340 & 523 & 402 & 423 & 694 & 547 & 622 & 695 & 213 \\
\hline Winter skate & Raja ocellata & 1 & 264 & 428 & 347 & 1066 & 2400 & 2878 & 3494 & 2368 & 932 \\
\hline Little skate & Raja erinacea & 606 & 691 & 129 & 219 & 1186 & 2317 & 5077 & 6030 & 4529 & 1278 \\
\hline Thorny skate & Raja radiata & & 156 & 83 & 25 & 395 & 568 & 790 & 438 & 303 & 94 \\
\hline Atlantic cod & Gadus morhua & 1040 & 651 & 796 & 1100 & 2642 & 2978 & 2650 & 2127 & 2342 & 484 \\
\hline Haddock & Melanogrammus aeglefinus & 857 & 843 & 704 & 361 & 375 & 271 & 55 & 126 & 1034 & 565 \\
\hline White hake & Urophycis tenuis & 347 & 250 & 273 & 1099 & 1567 & 2048 & 3405 & 2284 & 1079 & 377 \\
\hline Red hake & Urophycis chuss & 295 & 988 & 738 & 1666 & 1487 & 1859 & 2460 & 2481 & 2186 & 667 \\
\hline American paice & Hippoglossoides platessoides & 968 & 435 & 129 & 37 & 69 & 102 & 39 & 1 & 572 & 539 \\
\hline Yellowtail flounder & Limanda ferruginea & 602 & 427 & 244 & 457 & 91 & 107 & 35 & 30 & 846 & 742 \\
\hline Winter flounder & Pseudopleuronectes americanus & 3 & 649 & 1091 & 454 & 236 & 186 & 82 & 23 & 681 & 781 \\
\hline Longhorn sculpin & Myoxocephalus octodecemspinosus & 415 & 286 & 13 & 24 & 429 & 1281 & 2168 & 2399 & 1377 & 606 \\
\hline Ocean pout & Macrozoarces americanus & 232 & 196 & 48 & 58 & 54 & 24 & 20 & 21 & 572 & 508 \\
\hline
\end{tabular}


selectivity for broad taxonomic groups (e.g. most fit into Garrison \& Link's [2000] benthivore guild), but not specified selectivity within a broad, functional feeding group. Only smooth dogfish or ocean pout and American plaice are crab or echinoderm feeding specialists, respectively. Most of the predators used are opportunistic feeders (Link \& Almeida 2000, Link 2002) and given morphological and spatio-temporal constraints, exhibit diet compositions reflective of the dynamics of their particular prey field (e.g. Garrison \& Link 2000, Link \& Garrison 2002a,b, Link et al. 2002).

For each benthic prey species, 2 aspects were examined. First was the percent frequency of occurrence in the diet of all predators which met the criteria listed above. Percent frequency was chosen instead of percent diet composition because (1) diet composition is much more dynamic and susceptible to predator density-dependent and alternate prey influences than frequency of occurrence; (2) evidence from other studies suggests that this ecosystem is a donor-controlled, bottom-up driven ecosystem (Overholtz et al. 2000, Link 2002, Link \& Garrison 2002b), and any occurrence of a prey item in the stomach of a predator is ultimately indicative of its abundance in the ecosystem; and (3) frequency of occurrence is less biased than other diet estimators, in terms of predator selectivity, and simply represents how often a prey item was eaten or 'sampled' relative to the number of stomachs examined. The time-series began in 1973 and continued to 2001, with the data grouped into $3 \mathrm{yr}$ blocks, identified by the middle year. These estimates of frequency of occurrence were used as indices of relative abundance, similar to resource surveys. The criteria for an increasing, declining, or stationary trend was that more than half or 3 predators (whichever number was smaller), exhibited the same pattern across the time-series. This approach is analogous to multiple surveys for a particular species, with similar trends in relative abundance from multiple surveys confirming the patterns observed.

The other aspect examined was the geo-referenced location of a prey occurrence in the stomach of a predator. This was recorded as the beginning latitude and longitude of the tow in which the predator was caught with the prey item of interest in its stomach. All locations (all tows were part of a stratified random design; Azarovitz 1981) were then plotted for each predator to evaluate the spatial distribution of the particular benthic species of interest. The spatial extent ranged from latitude $39.0^{\circ}$ to $45.3^{\circ} \mathrm{N}$ and longitude $65.0^{\circ}$ to $75.0^{\circ} \mathrm{W}$, effectively the northeast shelf ecosystem exclusive of the middle Atlantic region and inclusive of portions of Canadian waters which were periodically surveyed (Fig. 1). Major regions or features of this ecosystem are Hudson Canyon (HC), typically characterized as soft clay or silt-mud sediments; Nantucket Shoals (N.S.), typically characterized as coarse-sand sediments, as is most of the central part of Georges Bank; Great South Channel (G.S.C.), typically characterized as gravel, gravelly sand, or rocky sediments; Wilkinson Basin (W.B.), typically characterized as silty

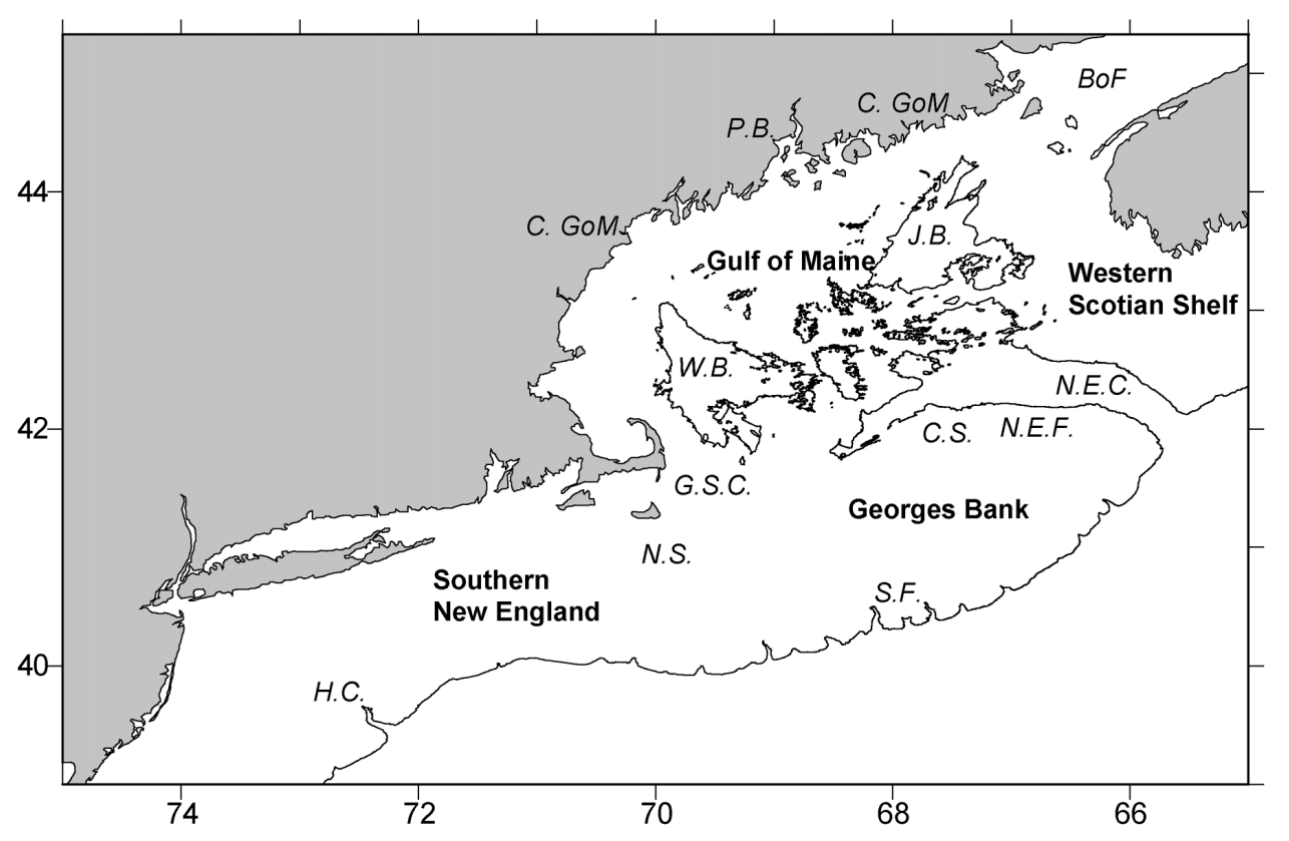

Fig. 1. Major regions (boldface) of the northeast US continental shelf (Western Scotian Shelf, Bay of Fundy, and portions of Georges Bank are in Canadian waters). Italicized labels denote major features of this ecosystem (see 'Materials and methods' for definitions and descriptions). Contour line represents the $200 \mathrm{~m}$ isobath 
sand, clay or mud sediments; Coastal Gulf of Maine (C. GoM), in both Massachusetts/New Hampshire and Maine waters, typically characterized as gravel, gravelly sand, or rocky sediments; Penobscot Bay (P.B.), typically characterized as mud or clay sediments; Jordan Basin (J.B.), typically characterized as gravel or gravelly sand and mud sediments; Bay of Fundy (BoF); Northeast Channel (N.E.C.), typically characterized as gravel or rocky sediments; Northeast Flank of Georges Bank (N.E.F.), typically characterized as gravel, gravelly sand or rocky sediments; Cultivator Shoals (C.S.), typically characterized as gravel or gravelly sand sediments; and Southern Flank of Georges Bank (S.F.), typically characterized as low-energy, fine-sand sediments. Typical sediment conditions for each area were taken from and are described in further detail in Theroux \& Wigley (1998) and Poppe et al. (1989).

The benthic macrofauna focused on were ophiuroids (brittle stars), echinoids (sand dollars Echinarachnius parma and sea urchins), holothuroideans (sea cucumbers), asteroids (starfish), octopods (octopus: Octopus spp. and Bathypolypus arcticus), stomatopods, caprellids, cumaceans, pagurids (hermit crabs Pagurus arcuatus), aphroditids (sea mouse Aphrodita hastata), anthozoans (anemones and soft corals) and hydrozoans (hydroids). I recognize that each broad taxonomic group could represent a suite of possible species but did not specify what species in a benthic group might be present in a stomach other than those listed above. Those species which are too small (e.g. meiofauna, deeper infauna) or too large (e.g. large coral colonies) to be readily consumed by these fishes should be the only organisms in each group reasonably ruled out as those not sampled by these fishes.

The predators examined were smooth dogfish Mustelus canis, winter skate Raja ocellata, little skate $R$. erinacea, thorny skate $R$. radiata, Atlantic cod Gadus morhua, haddock Melanogrammus aeglefinus, white hake Urophycis tenuis, red hake U. chuss, American plaice Hippoglossoides platessoides, yellowtail flounder Limanda ferruginea, winter flounder Pseudopleuronectes americanus, longhorn sculpin Муохо-

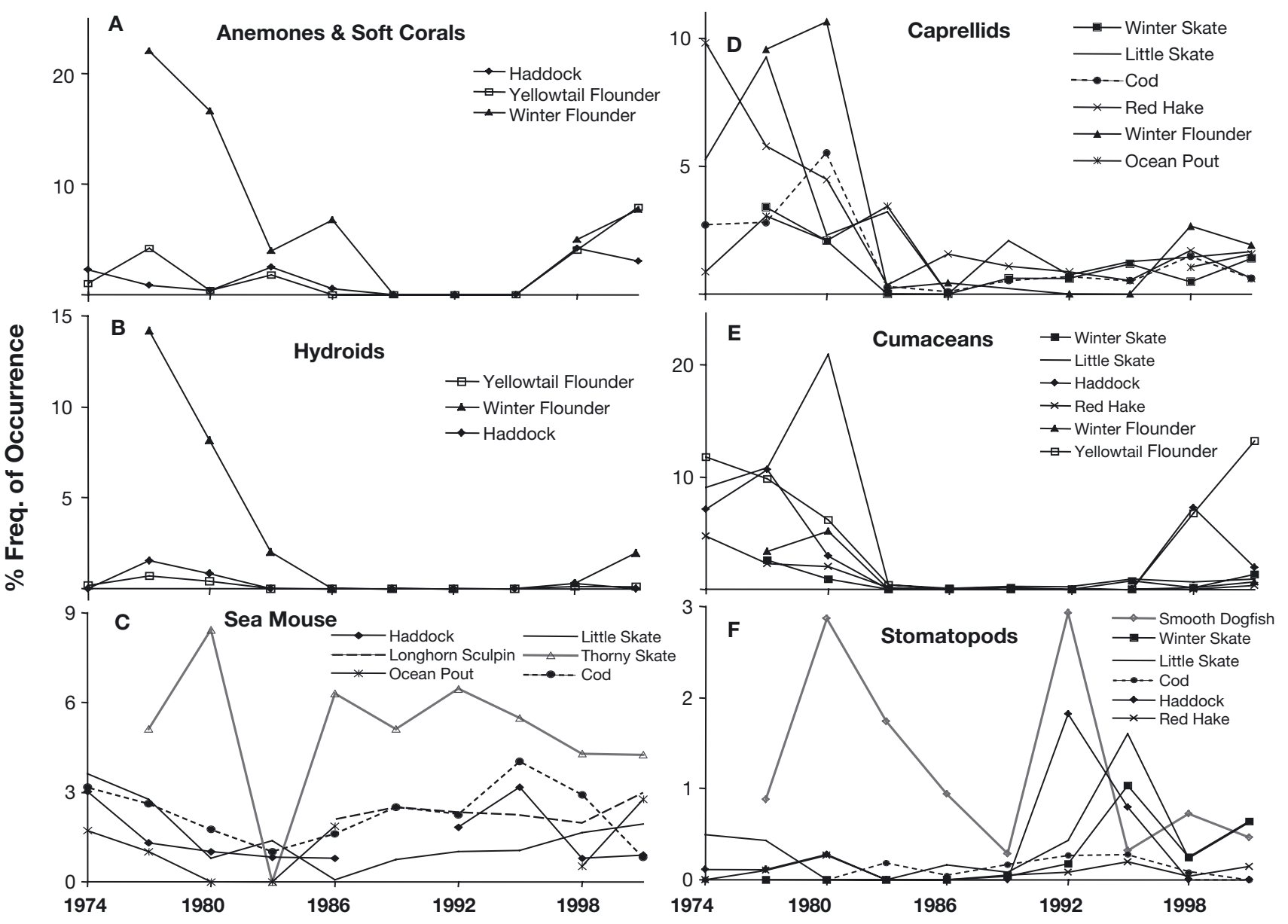

Fig. 2. Percent frequency of occurrence of common macrobenthic prey items in the stomachs of their major predators. Each year represents the mid-point of a 3 yr block in the time-series 
cephalus octodecemspinosus and ocean pout Macrozoarces americanus (Table 1). For further information and general details on the trophic dynamics of these fishes, see Link \& Almeida (2000).

\section{RESULTS}

Across the time-series, over half of the benthos examined did not exhibit any clear trend (Figs. 2 \& 3). Of the 12 benthic groups examined, only 3 (caprellids, cumaceans, and pagurids) declined across the timeseries (Figs. 2D,E \& 3A). All 3 showed a simultaneous decline from the 1970s and early 1980s, with no signs of increasing in the later years (Figs. 2D,E \& 3A). Anemones and hydroids declined in the diet of winter flounder, but not in the diet of the other 2 predators (Fig. 2A,B); these 2 prey items occurred very infrequently or not at all in the diet of predators during the 1980s and early 1990s. Conversely, starfish and stomatopods increased slightly in the 1990s and early 2000s (Figs. 2F \& 3F), although some of the major predators of starfish (haddock, American plaice, ocean pout) had a lower sample size or no starfish in the diet during some portions of the 1990s. Nevertheless, starfish may be currently increasing, as shown in other studies for more localized parts of this ecosystem (Link et al. in press). However, the increases in both starfish (except in ocean pout) and stomatopods are less than $3 \%$.

The other benthic prey organisms have exhibited no clear pattern, conflicting patterns in the stomachs of their predators, or a relatively stationary index of abundance over the past 30 yr. Hydroids, stomatopods, starfish (except in ocean pout), octopods, and sea cucumbers were less common than the other benthic organisms (Figs. 2B,F \& 3B,E,F).

Most organisms exhibited a wide range of distribution across the northeast shelf ecosystem (Figs. 4-6). There were 3 main types of distribution patterns: Gulf of Maine (rocky), Georges Bank or Southern New England (sandy), or widespread. Sea cucumbers, brittle
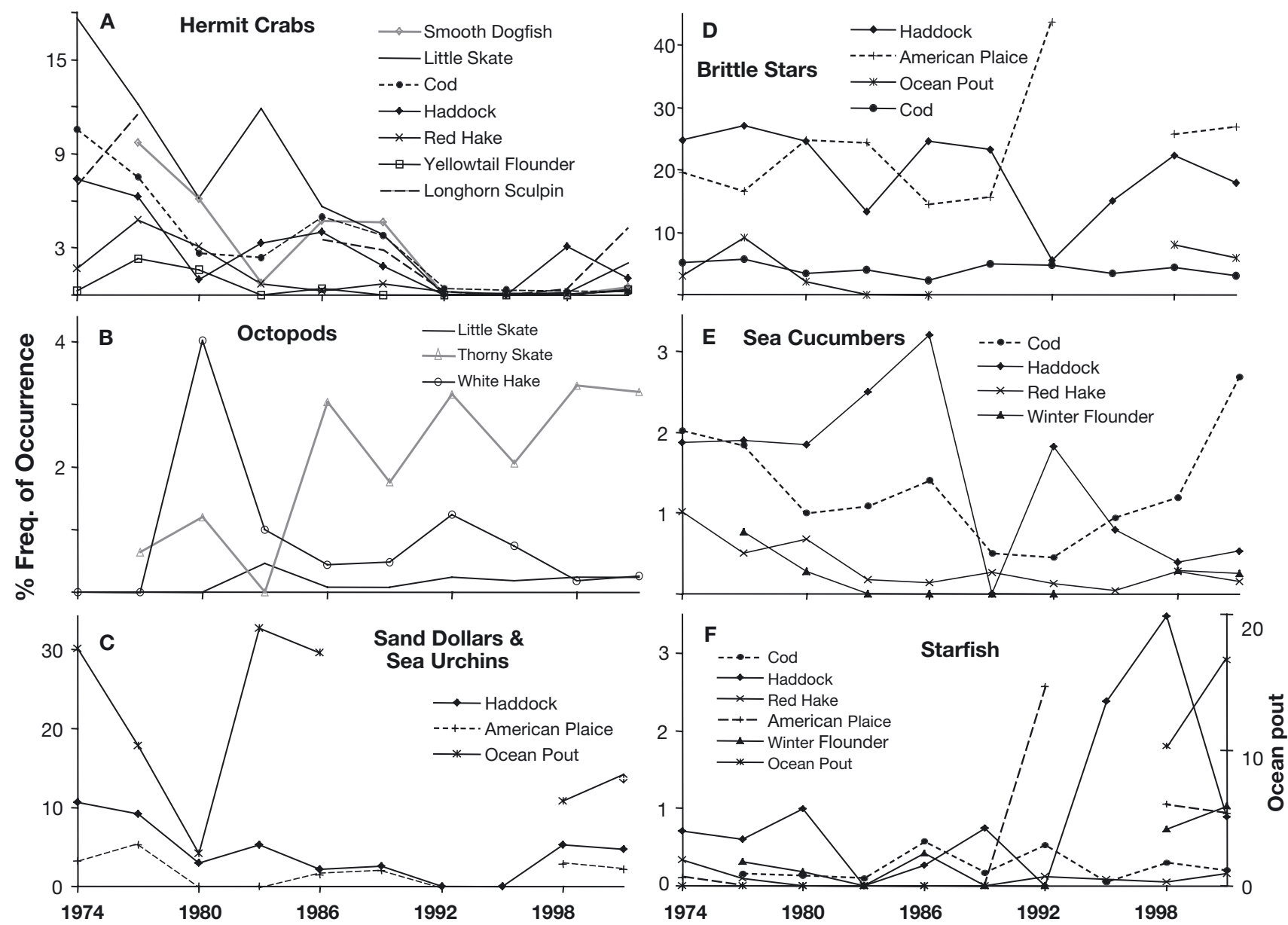

Fig. 3. Percent frequency of occurrence of common macrobenthic prey items in the stomachs of their major predators. Each year represents the mid-point of a $3 \mathrm{yr}$ block in the time-series. Starfish data $(\mathrm{F})$ have a secondary axis showing percent occurrence in ocean pout 
A
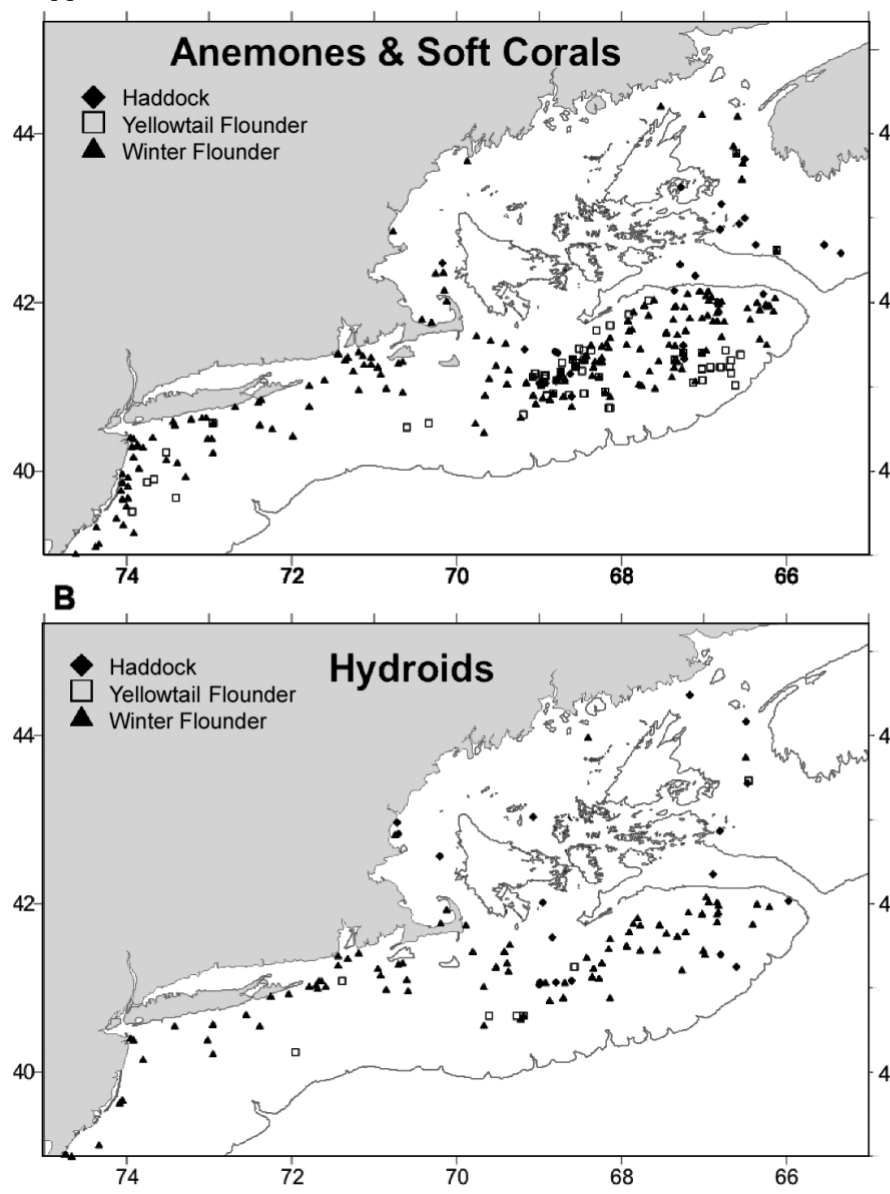

C

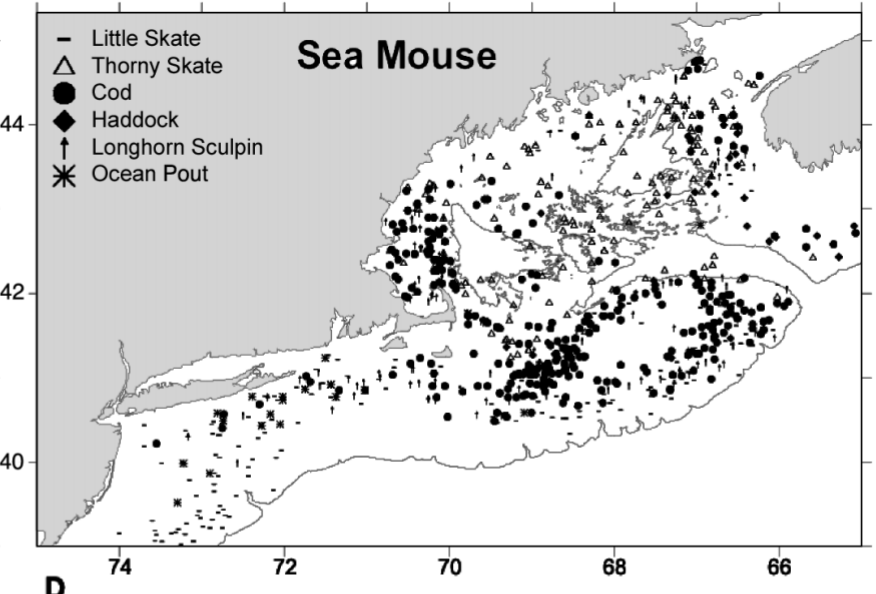

D

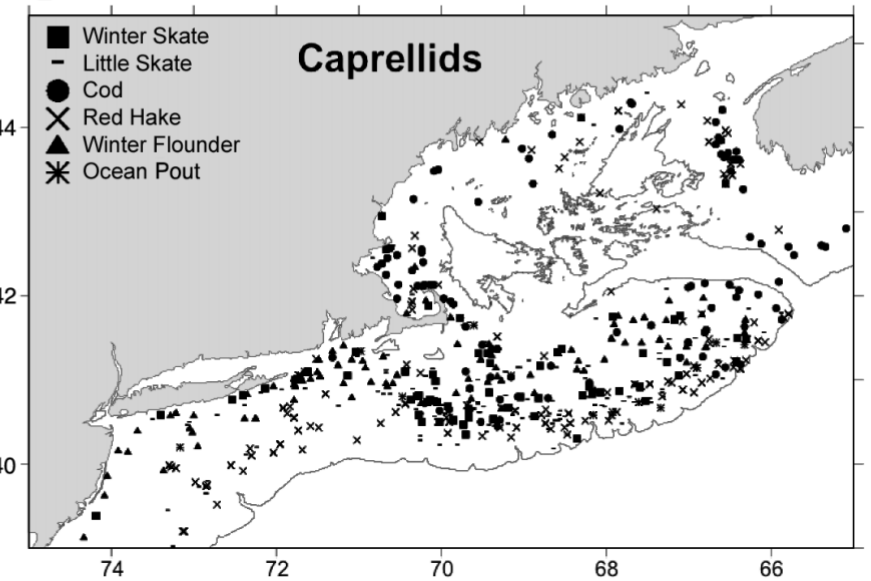

Fig. 4. Distributions of common macrobenthic prey as sampled from the stomachs of their major predators. Each location represents the beginning latitude and longitude of a tow in which the predator was caught with that benthic organism in the stomach. Symbols are different for each predator. Contour line represents the $200 \mathrm{~m}$ isobath

stars, and octopods were primarily associated with the Gulf of Maine or rocky bottom areas such as the Great South Channel or Northeast Flank (Figs. 5D \& 6B,C). Brittle stars were the only macrobenthos that occurred commonly in the deeper basins of the Gulf of Maine (Fig. 6B). Brittle stars and sea cucumbers were the only macrobenthos that occurred commonly in the Northeast Channel (Fig. 6B,C). Hermit crabs were primarily associated with Georges Bank cobble areas such as the Great South Channel or the Northeast Flank (Fig. 5C).

Hydroids, stomatopods, cumaceans, anemones or soft corals, sand dollars, sea urchins and starfish were principally located on central Georges Bank and southern New England, associated with coarse sand substrates (Figs. 4A,B, 5A,B \& 6A,D). The remaining macrobenthos (sea mouse and caprellids) were widely distributed throughout the ecosystem (Fig. 4C,D). Stomatopods and hydroids were not as common nor widely distributed as the other benthos, probably because of their lower frequencies of occurrence.

Comparison with the distributions of benthos from 1956 to 1965 plotted by Theroux \& Wigley (1998)
$(\mathrm{T} \& \mathrm{~W})$ revealed that anemones and corals $(\mathrm{T} \& \mathrm{~W}$ their Fig. 45 vs present Fig. 4A), sea mouse (T\&W Fig. 244 vs Fig. 4C), cumaceans (T\&W Fig. 154 vs Fig. 5A), hermit crabs (T\&W Fig. 248 vs Fig. 5C), sand dollars and sea urchins (T\&W Fig. 214 \& 249 vs Fig. 6A), brittle stars (T\&W Figs. $220 \& 249$ vs Fig. 6B), and sea cucumbers (T\&W Fig. 208 vs Fig. 6C) all exhibited distribution patterns in the 1950s/1960s similar to the more recent data presented in this study. Only starfish (T\&W Figs. 225 \& 249 vs Fig. 6D) exhibited a change in distribution from the 1950s/1960s to more recent years, with fewer occurrences in the southern flank region at present than in the past. It appears that all these distribution patterns are related to sediment or substrate type, and may actually be indicative of particular habitats (Theroux \& Wigley 1998). Unfortunately, contemporary and synoptic estimates of benthos abundance and biomass do not exist for comparison with those from the 1950s/1960s, but for the vast majority ( 8 of the 9 ) of organisms compared, the general distribution patterns have not notably altered across 5 decades. 

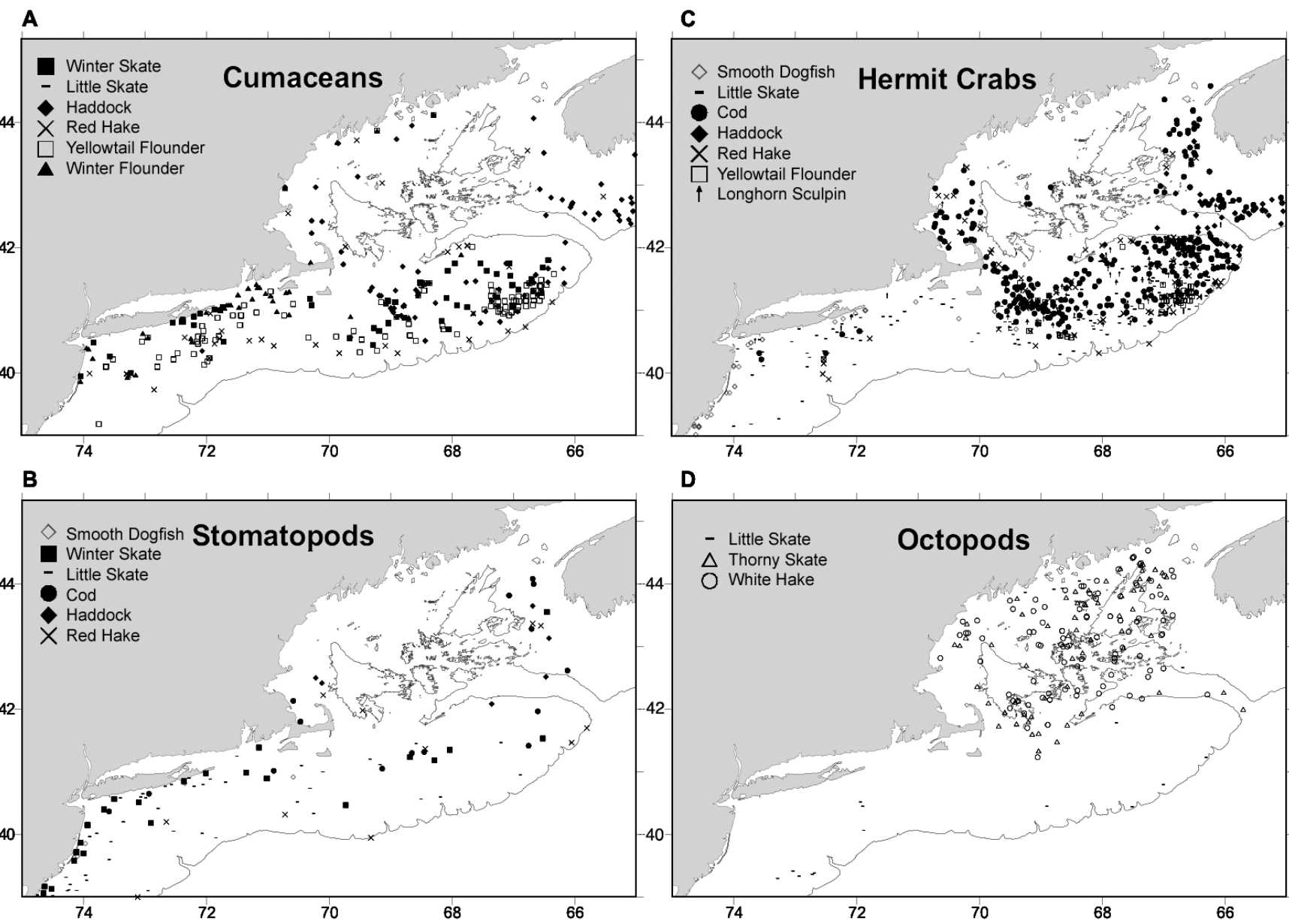

Fig. 5. Distributions of common macrobenthic prey as sampled from the stomachs of their major predators. Further details as in Fig. 4

\section{DISCUSSION}

The majority of the benthos did not decline over the past 30 yr. Most benthos showed no trend and 2 groups actually showed a slight increase in their index of relative abundance. Additionally, there were minimal differences in the observed distributions of benthos in this study compared to data from the 1950s/1960s (Theroux \& Wigley 1998). These observations were somewhat surprising given both the acute impacts of fishing gear to the ocean bottom that we know can affect a localized area (e.g. Thrush et al. 1995, Jennings \& Polunin 1996, Kaiser \& Spencer 1996, Collie et al. 1997, 2000, Engel \& Kvitek 1998, Tuck et al. 1998, Auster \& Langton 1999, Ball et al. 2000) and the suspected widespread, consistent, and chronic extent of bottomtending fishing activities in this ecosystem (Watling \& Norse 1998, Auster \& Langton 1999). Integrating negative, localized and acute events across chronic, longterm and widespread scales should not logically result in a positive or non-negative outcome, yet this appears to be the outcome of this study. Why are these results so contrary to the bulk of the literature on the topic and so seemingly counter-intuitive? That is, why were indices of benthos abundance not declining as expected?

One reason these results could contrast with much of the literature is the caveats of these sampling devices. Fish stomachs cannot provide estimates of absolute abundance and biomass of the benthos, thus limiting the possibility of spatio-temporal and cross-study comparisons. Using stomachs to produce a temporal index, even of relative abundance, may be neglecting key elements of the predation process. In particular, if there is a heretofore unknown degree of predator selectivity the indices could be biased in any number of directions. Despite the careful screening criteria for the predators used in this study, it is possible that some of these fishes could be feeding more selectively than suspected. However, there are 4 lines of evidence which suggest that our sampling may not be any more biased than other methods and that the observed trends may in fact be reasonable. First, studies on southern Georges Bank closed areas (Link et al. in 

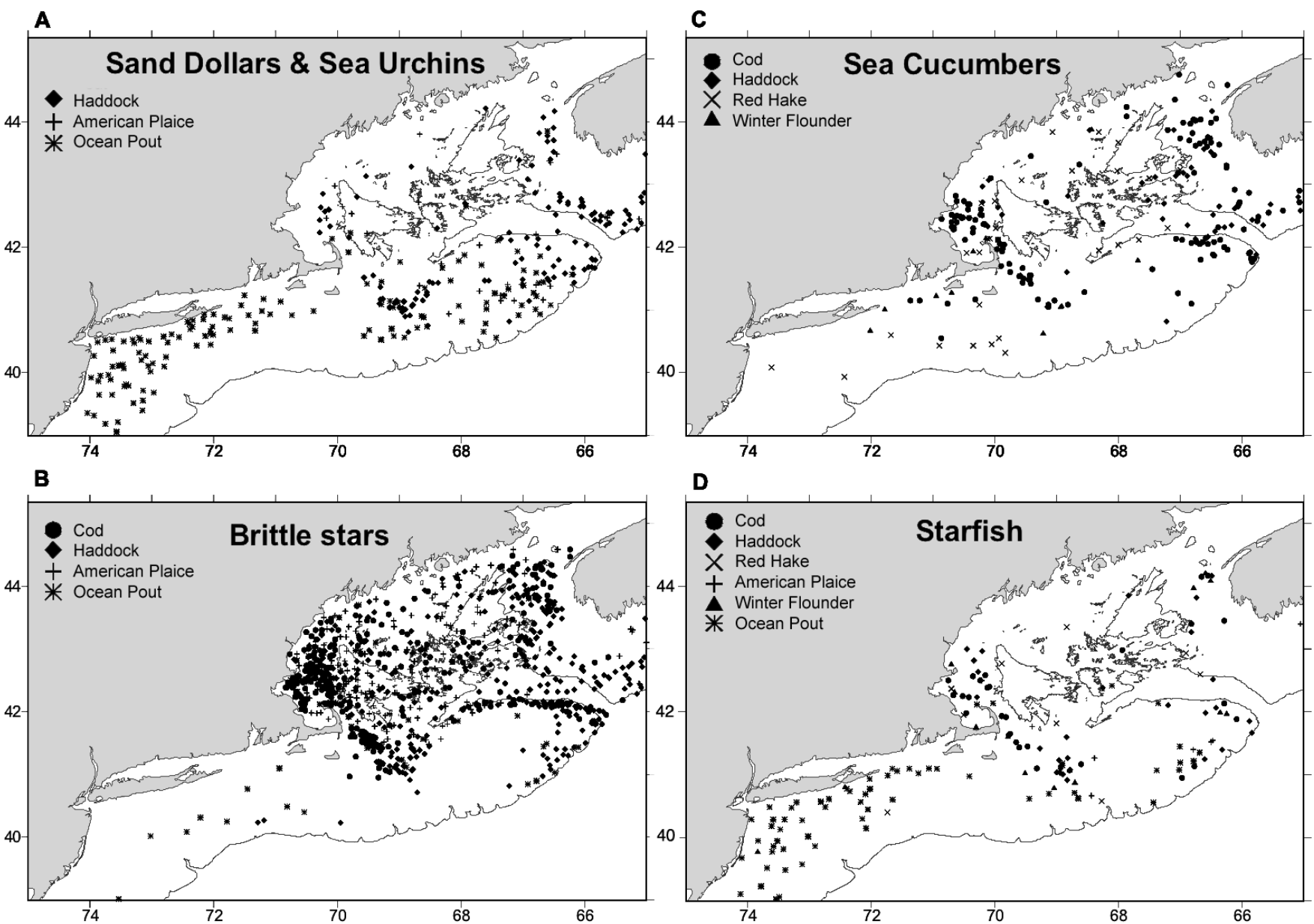

Fig. 6. Distributions of common macrobenthic prey as sampled from the stomachs of their major predators. Further details as in Fig. 4

press) generally show minimal differences in stomach contents between inside and outside some of the closed areas, consistent with the trends observed for many of the species living in sandy regions. Second, the diets of most fishes in the closed area studies reflect the localized benthic prey field (Link et al. in press). Third, estimates of absolute abundance and biomass from the closed area studies in the late 1990s (Link et al. in press) are strikingly similar to those presented by Theroux \& Wigley (1998) for the 1950s/1960s. Finally, there is effectively little difference in the distribution of benthos between this study and Theroux \& Wigley's (1998) study, suggesting that benthic organisms occur in the same general habitats. Other studies have similarly used fish samplers successfully to evaluate the dynamics of benthic prey populations and communities (e.g. Lilly \& Parsons 1991, Fahrig et al. 1993, Rachlin \& Warkentine 1997, Frid \& Hall 1999), so the use of fish stomachs as samplers of the benthos should not be summarily discounted despite the caveats of this approach.
Most studies on fishing impacts (e.g. Thrush et al. 1995, Auster et al. 1996, Jennings \& Polunin 1996, Kaiser \& Spencer 1996, MacDonald et al. 1996, Collie et al. 1997, 2000, Engel \& Kvitek 1998, Thrush et al. 1998, Tuck et al. 1998, Auster \& Langton 1999, Ball et al. 2000, Jennings et al. 2002, Kaiser 2003) and a suite of other impacts (e.g. Weston 1990, Montagna \& Harper 1996, Pogrebov et al. 1997, Desprez 2000, Sager 2002) to the ocean bottom are acute. Certainly bottom-tending fishing gear, drilling, dumping, toxic spills, etc. can alter many aspects of a local area for a short period of time. Yet these impacts may be subsumed in the long-term dynamics of chronic natural disturbances suspected to affect the ocean benthos (Kaiser \& Spencer 1996, Posey et al. 1996, Kaiser 1998, Frid \& Clark 2000, Kaiser et al. 2002).

Those studies of fishing impacts to the ocean bottom that are chronic and long-term are also usually localized (e.g. Frid et al. 1996, 2000, Hill et al. 1999, HallSpencer \& Moore 2000; reviewed by Collie et al. 2000). It is very difficult to maintain a long time-series of ben- 
thic surveying or monitoring. Most such surveys comprise a few stations that are repeatedly sampled, and most of these are primarily coastal. Kaiser (2003) discussed the importance of spatial scale when evaluating these disturbances, noting how difficult it is to sample at appropriate levels and subsequently interpret results accordingly. Given the patchy nature of benthos, the sampling in the present study may have been too coarse to detect notable trends in abundance or distribution; however fishes are likely to be effective integrators of the benthos across biologically meaningful scales. Kaiser (1998, 2003), Collie et al. (2000) and Kaiser et al. (2002) noted that the sum results from these chronic but localized studies have been ambiguous, with the most detrimental impacts observed in high-relief substrates.

Those few studies which do show impacts from fishing to the ocean bottom that are chronic, long-term and that are also broad-scale have reported effects only on certain biota (Kiyko \& Pogrebov 1997, Probert et al. 1997, Thrush et al. 1998, Frid \& Hall 1999, Frid \& Clark 2000, McConnaughey et al. 2000, Jennings et al. 2001, 2002). Multiple reviews and meta-analyses have noted that anthozoans, bivalves, polychaetes, ophiuroids, echinoids, gastropods, some crustaceans, and similarly 'brittle' organisms are most severely affected by fishing impacts to the ocean bottom (see reviews by Hall 1999, Collie et al. 2000, Kaiser et al. 2002). The same is true for the northeast shelf ecosystem (e.g. Collie et al. 1997, 2000), where area closures have resulted in more protection from bottom-tending fishing impacts and the subsequent positive response of commercially valuable bivalves, i.e. scallops (Murawski et al. 2000). This pattern is consistent with the abundance patterns of some of the organisms in this study over the last decade (6 to $10 \mathrm{yr}$ ). Most of those organisms in this study which did not decline in abundance are not members of the more fragile groups. Echinoderms (especially ophiuroids) were the only organisms that would have been expected to decline, based upon prior studies and reviews (Thrush et al. 1998, Collie et al. 2000, Kaiser et al. 2002, Kaiser 2003), but did not do so in this study. Those organisms that did decline can reasonably be understood to be strongly impacted by fishing gear; for instance the shells of hermit crabs are brittle enough to be cracked or small epibenthic crustaceans are likely to be broken. Those species that exhibited non-negative or positive trends (particularly starfish) are either scavengers, have life histories and growth rates adapted for disturbance, have a high discard survivability, or can regenerate body parts (e.g. hydroids, starfish, etc.). Other studies have shown similar patterns for these types of scavenging or highly discarded organisms (Ramsay et al. 1998, 2000, Thrush et al. 1998, Frid \& Hall 1999). With a few exceptions, most of the highly susceptible organisms noted in other studies are usually not targeted by fisheries nor constitute a large amount of the food eaten by fish; thus they may ultimately be minimally impacted by fish and fisheries.

Upon further reflection, the results of the present study are not entirely different from those of some more recent and synthesizing studies of fishing gear impacts to the ocean bottom (e.g. Collie et al. 2000, Kaiser et al. 2002, Kaiser 2003) or those that reported effects on only specific benthic organisms (Thrush et al. 1998, Frid \& Clark 2000, McConnaughey et al. 2000, Jennings et al. 2001, 2002). Once we have accounted for spatial scale, long-term observations, known natural disturbances, substrate type, and the type of benthic organism examined, the results that initially seemed so counter-intuitive appear more reasonable. Some types of substrate, particularly high-energy sand, have shown relatively rapid recovery times from acute effects of bottom-tending fishing gear (Watling \& Norse 1998, Auster \& Langton 1999, Collie et al. 2000). Additionally, the organisms associated with such sediments are already adapted to common and routine natural disturbances. Those organisms inhabiting gravelly or rocky areas may be afforded some degree of protection through fishermen avoiding such substrates in order to protect their fishing gear (see map in Auster \& Langton 1999, Link \& Demarest 2003). In contrast to locales subjected to multiple uses (and hence disturbances), this ecosystem is not exposed to other human disturbances (e.g. drilling, dredging, deposition, etc.), which when combined can overwhelm natural processes in an ecosystem. This ecosystem is also highly productive (Cohen et al. 1982, Sissenwine et al. 1984), which may also partially compensate any extra mortality experienced by the benthos from bottom-tending gear impacts.

The results of this study do not mean that we should cease to study the benthos or develop novel technologies to sample them. Rather, we need to recognize the limitations of those approaches and continue to unravel the truly challenging, complex nature of identifying chronic effects in the marine benthos. One weakness of the present study was the broad taxonomic resolution used for the benthos. For instance, some polychaetes and amphipods are known to be sensitive to gear effects (Thrush et al. 1998, Collie et al. 2000, Kaiser et al. 2002, Kaiser 2003) and the present taxonomic precision of prey sampling did not allow meaningful evaluation of polychaetes or amphipods, or species within these groups, across the time-series. It is also possible that some of the groups evaluated could include species with notable individual patterns that were lost when amalgamated into the broader taxonomic groups. However, the tradeoffs between higher taxonomic resolution of benthos versus cost- and time- 
effectiveness at lower resolutions will always remain regardless of sampling device or intensity.

Additionally, the results of this study do not mean that fishing gear or other disturbances to the ocean bottom do not affect the benthos. Rather, at the scales on which fisheries operate, such disturbances are probably amalgamated by a suite of other processes for most of the benthos examined in this study. The role and importance of other disturbances to the ocean bottom relative to fishing impacts merit further study. These limited effects are not license for reducing concern over gear impacts (Watling \& Norse 1998) and the precautionary approach (FAO 1996, Auster 2001) still applies. Yet the apparent relative stability or at least resiliency of many benthic organisms in the northeast US shelf ecosystem suggests that not all news associated with fisheries impacts are negative. Perhaps highly dynamic short-term processes affecting benthic communities lead to long-term overall community stability, and fishing as a disturbance may well be within the range of the natural short-term dynamics influencing benthic communities (Kaiser \& Spencer 1996, Posey et al. 1996, Kaiser 1998, Frid \& Clark 2000, Kaiser et al. 2002). Or more sobering, perhaps the benthic community of the northeast US shelf ecosystem has already been altered after centuries of fishing, and the reason for the few notable changes over the past $30-50 \mathrm{yr}$ is that the major changes had already occurred prior to this time. Thus, we may now be in an alternate state.

This study affirms the utility of implementing fish stomachs as samplers of the benthos. Given the difficulty and expense of routinely and synoptically sampling the benthos, sampling them by proxy using fish stomachs that have met carefully screened criteria may be a reasonable alternative approach. Very few data sets allow us to ascertain the broad spatial distribution and temporal abundance of benthic communities, but re-examining extant food habits data may provide such ancillary data with respect to the benthos. This approach is cost-effective, more efficient, and easier to implement 'piggy-backed' onto extant fisheries surveys than initiating exhaustive and technologically advanced benthic surveys. I conclude that at broad spatial and temporal scales, the routine and systematic sampling of fish stomachs can be a useful indirect method for inferring information about benthic communities on continental shelves.

Acknowledgements. I thank past and present FWDP staff for their dedicated efforts in auditing, maintaining, and establishing the food habits database. I thank F. Almeida, M. Fogarty, W. Gabriel and T. Noji for discussions during the development of some ideas for this paper. I thank P. Auster, M. Kaiser, J. Collie, J. Lindholm, T. Noji and anonymous reviewers for insightful comments on prior versions of this manuscript.

\section{LITERATURE CITED}

Auster PJ (2001) Defining thresholds for precautionary habitat management actions in a fisheries context. N Am J Fish Manag 21:1-9

Auster PJ, Langton RW (1999) The effects of fishing on fish habitat. Am Fish Soc Symp 22:150-187

Auster PJ, Malatesta RJ, Langton RW, Watling L and 5 others (1996) The impacts of mobile fishing gear on seafloor habitats in the Gulf of Maine (northwest Atlantic): implications for conservation of fish populations. Rev Fish Sci 4:185-202

Azarovitz TR (1981) A brief historical review of the Woods Hole Laboratory trawl survey time series. Can Spec Publ Fish Aquat Sci 58:62-67

Ball BJ, Fox G, Munday BW (2000) Long- and short-term consequences of a Nephrops trawl fishery on the benthos and environment of the Irish Sea. ICES J Mar Sci 57: 1315-1320

Benaka L (ed) (1999) Fish habitat: essential fish habitat and rehabilitation. Adv Food Sci Symp 22:459

Cohen EB, Grosslein MD, Sissenwine MP, Steimle F, Wright WR (1982) Energy budget of Georges Bank. Can Spec Publ Fish Aquat Sci 59:95-107

Collie JS, Escanero GA, Valentine PC (1997) Effects of bottom fishing on the benthic megafauna of Georges Bank. Mar Ecol Prog Ser 155:159-172

Collie JS, Hall SJ, Kaiser MJ, Poiner IR (2000) A quantitative analysis of impacts on shelf-sea benthos. J Anim Ecol 69: 785-798

Desprez M (2000) Physical and biological impact of marine aggregate extraction along the French coast of the Eastern English Channel: short- and long-term post-dredging restoration. ICES J Mar Sci 57:1428-1438

Eleftheriou A (2000) Marine benthos dynamics: environmental and fisheries impacts. Introduction and overview. ICES J Mar Sci 57:1299-1302

Engel J, Kvitek R (1998) Effects of otter trawling on a benthic community in Monterey Bay National Marine Sanctuary. Conserv Biol 12:1204-1214

Fahrig L, Lilly GR, Miller DS (1993) Predator stomachs as sampling tools for prey distribution: Atlantic cod (Gadus morhua) and capelin (Mallotus villosus). Can J Fish Aquat Sci 50:1541-1547

FAO (Food and Agriculture Organization of the United Nations) (1996) Precautionary approach to fisheries, Part 2, scientific papers. FAO Fish Tech Pap 350/2. FAO, Rome.

Frid CLJ, Clark RA (2000) Long-term changes in North Sea benthos: discerning the role of fisheries. In: Kaiser MJ, deGroot SJ (eds) Effects of fishing on non-target species and habitats, Blackwell Science, Oxford, p 198-216

Frid CLJ, Hall SJ (1999) Inferring changes in North Sea benthos from fish stomach analysis. Mar Ecol Prog Ser 184:183-188

Frid CLJ, Buchanan JP, Garwood PR (1996) Variability and stability in benthos: twenty-two years of monitoring off Northumberland. ICES J Mar Sci 53:978-980

Frid CLJ, Harwood KG, Hall SJ, Hall JA (2000) Long-term changes in the benthic communities on North Sea fishing grounds. ICES J Mar Sci 57:1303-1309

Garrison LP, Link JS (2000) Dietary guild structure of the fish community in the northeast United States continental shelf ecosystem. Mar Ecol Prog Ser 202:231-240

Hall SJ (1999) The effects of fishing on marine ecosystems and communities, Blackwell Science, Oxford

Hall-Spencer JM, Moore PG (2000) Scallop dredging has profound, long-term impacts on maerl habitats. ICES J Mar Sci 57:1407-1415 
Hill AS, Veale LO, Pennington D, Whyte SG, Brand AR, Hartnoll RG (1999) Changes in Irish Sea benthos: possible effects of 40 years of dredging. Estuar Coast Shelf Sci. 48: $739-750$

Jennings S, Kaiser MJ (1998) The effects of fishing on marine ecosystems. Adv Mar Biol 34:203-352

Jennings S, Polunin NVC (1996) Effects of fishing effort and catch rate upon the structure and biomass of Fijian reef fisheries. J Fish Biol 46:28-46

Jennings S, Dinmore TA, Duplisea DA, Warr KJ, Lancaster JE (2001) Trawling disturbance can modify benthic production processes. J Anim Ecol 70:459-475

Jennings S, Nicholson MD, Dinmore TA, Lancaster JE (2002) Effects of chronic trawling disturbance on the production of infaunal communities. Mar Ecol Prog Ser 243:251-260

Kaiser MJ (1998) Significance of bottom-fishing disturbance. Conserv Biol 12:1230-1235

Kaiser MJ (2003) Detecting the effects of fishing on seabed community diversity: importance of scale and sample size. Conserv Biol 17:512-520

Kaiser MJ, de Groot SJ (2000) Effects of fishing on non-target species and habitats, Blackwell Science, Oxford

Kaiser MJ, Spencer BE (1996) The effects of beam-trawl disturbance on infaunal communities in different habitats. J Anim Ecol 65:348-358

Kaiser MJ, Collie JS, Hall SJ, Jennings S, Poiner IR (2002) Modification of marine habitats by trawling activities: prognosis and solutions. Fish Fish (Oxf) 3:114-136

Kiyko OA, Pogrebov VB (1997) Long-term benthic population changes (1920-1930s-Present) in the Barents and Kara Seas. Mar Pollut Bull 35:322-332

Lilly GR, Parsons DG (1991) Distributional patterns of the northern shrimp (Pandalus borealis) in the Northwest Atlantic as inferred from stomach contents of cod (Gadus morhua). Int Counc Explor Sea Comm Meet 1991/K:41

Link JS (2002) Does food web theory work for marine ecosystems? Mar Ecol Prog Ser 230:1-9

Link JS, Almeida FP (2000) An overview and history of the food web dynamics program of the Northeast Fisheries Science Center, Woods Hole, Massachusetts. NOAA Tech Memo NMFS-NE-159:60

Link, JS, Demarest C (2003) Trawl hangs, baby fish, and closed areas: a win-win scenario. ICES J Mar Sci 60:930-938

Link JS, Garrison LP (2002a) Trophic ecology of Atlantic cod Gadus morhua on the Northeast US Continental Shelf. Mar Ecol Prog Ser 227:109-123

Link JS, Garrison LP (2002b) Changes in piscivory associated with fishing induced changes to the finfish community on Georges Bank. Fish Res 55:71-86

Link J, Bolles K, Milliken C (2002) The feeding ecology of flatfish in the Northwest Atlantic. J Northwest Atl Fish Sci $30: 1-17$

Link J, Almeida F, Valentine P, Auster P, Reid R, Vitaliano J (in press) The effect of area closures on Georges Bank. Am Fish Soc Spec Symp

MacDonald DS, Little M, Eno NC, Hiscock K (1996) Disturbance of benthic species by fishing activities: a sensitivity index. Aquat Conserv Mar Freshw Ecosyst 6:257-268

McConnaughey RA, Mier KL, Dew CB (2000) An examination of chronic trawling effects on soft-bottom benthos of the eastern Bering Sea. ICES J Mar Sci 57:1377-1388

Montagna PA, Harper DE (1996) Benthic infaunal long-term response to offshore production platforms in the Gulf of Mexico. Can J Fish Aquat Sci 53:2567-2588

Editorial responsibility: Kenneth Sherman (Contributing Editor), Narragansett, Rhode Island, USA
Murawski SA, Brown R, Lai H L, Rago PJ, Hendrickson L (2000) Large-scale closed areas as a fishery-management tool in temperate marine systems: the Georges Bank experience. Bull Mar Sci 66:775-798

Overholtz W, Link JS, Suslowicz LE (2000) The impact and implications of fish predation on pelagic fish and squid on the eastern USA shelf. ICES J Mar Sci 57:1147-1159

Pogrebov VB, Fokin SI, Galtsova VV, Ivanov GI (1997) Benthic communities as influenced by nuclear testing and radioactive waste disposal off Novaya Zemlya in the Russian Arctic. Mar Pollut Bull 35:333-339

Poppe LJ, Schlee JS, Butman B, Lane CM (1989) Map showing distribution of surficial sediment, Gulf of Maine and Georges Bank. US Geological Survey Miscellaneous Investigations Series, Map 1-1986-A. USGS, Woods Hole, MA

Posey M, Lindberg W, Alphin T, Vose F (1996) Influence of storm disturbance on an offshore benthic community. Bull Mar Sci 59:523-529

Probert PK, McKnight DG, Grove SL (1997) Benthic invertebrate bycatch from a deep-water trawl fishery, Chatham Rise, New Zealand. Aquat Conserv Mar Freshwater Ecosyst 7:27-40

Rachlin JW, Warkentine BE (1997) Comments on the population structure of the benthic marine isopod Politlana concharum collected by the Atlantic sturgeon, Acipenser oxyrhynchus. Crustaceana 70:368-379

Ramsay K, Kaiser MJ, Hughes RN (1998) The responses of benthic scavengers to fishing disturbance by towed gears in different habitats. J Exp Mar Biol Ecol 224:73-89

Ramsay K, Kaiser MJ, Rijnsdopr AD, Craeymeersch JA, Ellis J (2000) Impact of trawling on populations of the invertebrate scavenger Asterias rubens. In: Kaiser MJ, deGroot SJ (eds) Effects of fishing on non-target species and habitats. Blackwell Science, Oxford, p 151-162

Sager DR (2002) Long-term variation in mercury concentrations in estuarine organisms with changes in releases into Lavaca Bay, Texas. Mar Pollut Bull 44:807-815

Sissenwine, MP, Cohen EB, Grosslein MD (1984) Structure of the Georges Bank ecosystem. Rapp P-V Réun Cons Int Explor Mer 183:243-254

Theroux RB, Wigley RL (1998) Quantitative composition and distribution of the macrobenthic invertebrate fauna of the continental shelf ecosystems of the northeastern United States. NOAA Tech Rep NMFS 140:240

Thrush, SF, Hewitt JE, Cummings VJ, Dayton PK (1995) The impact of habitat disturbance by scallop dredging on marine benthic communities: what can be predicted from the results of experiments? Mar Ecol Prog Ser 129: $141-150$

Thrush, SF, Hewitt JE, Cummings VJ, Dayton PK and 6 others (1998) Disturbance of the marine benthic habitat by commercial fishing: impacts at the scale of the fishery. Ecol Appl 8:866-879

Tuck I, Hall S, Robertson M, Armstrong E, Basford D (1998) Effects of physical trawling disturbance in a previously unfished sheltered Scottish sea loch. Mar Ecol Prog Ser 162:227-242

Watling L, Norse EA (1998) Disturbance of the seabed by mobile fishing gear: a comparison to forest clearcutting. Conserv Biol 12:1180-1197

Weston DP (1990) Quantitative examination of macrobenthic community changes along an organic enrichment gradient. Mar Ecol Prog Ser 61:233-244

Submitted: June 21, 2003; Accepted: November 17, 2003

Proofs received from author(s): March 9, 2004 